\title{
A adoção no Brasil: algumas reflexões
}

\section{Adoption in Brazil: some reflections}

\section{Ana Andréa Barbosa Maux*}

Faculdade de Ciências, Cultura e Extensão do Rio Grande do Norte - FACEX, Natal, RN, Brasil

\section{Elza Dutra**}

Universidade Federal do Rio Grande do Norte - UFRN, Natal, RN, Brasil

\begin{abstract}
RESUMO
O objetivo do presente artigo é desenvolver reflexões a respeito da cultura da prática da adoção no Brasil, as mudanças acontecidas no decorrer dos nossos cinco séculos de história e como se constituem hoje as famílias adotivas em nosso país. Embora a prática da adoção tenha assumido diversos lugares, alguns de destaque e outros de ostracismo no decorrer da história ocidental, no Brasil, o aspecto da caridade, presente nas primeiras adoções realizadas perpassa o imaginário social até os dias atuais, embora a prática mostre um cenário diferente no que diz respeito a este tipo de filiação. Ampliar a imagem social sobre a adoção, possibilitando uma desmistificação de idéias enraizadas somente acontecerá quando o assunto deixar de ser preocupação somente das famílias por adoção e de alguns profissionais que trabalham com a temática, e passar a se constituir em interesse da sociedade geral.
\end{abstract}

Palavras-chave: Adoção, Psicologia jurídica, Família, Parentalidade.

\begin{abstract}
The goal of the present article is to rise reflections regarding the culture of adoption in Brazil, the changes happened during our five centuries of history and how the adoptive families are constituted today in our country. Although the practice of adoption has assumed several places, some of them emphasized and others of ostracism during the Occidental history, in Brazil the aspect of charity presented in the first adoptions highlight the social imaginary until the current days, even though the practice show a different scene regarding to this type of parenthood. To extend the social image on the adoption, making possible a reconstruction of rooted ideas will only happen when the subject is not only a concern of the families who wish for adoption or some professionals who work with it but the interest of the general society.
\end{abstract}

Keywords: Adoption, Forensic psychology, Family, Parenthood. 


\section{I ntrodução}

A adoção parece ser o tema do momento. Basta uma rápida olhada nas novelas exibidas pela principal rede de televisão do país para perceber que, em todas elas, sem exceção, o tema da adoção se faz presente. Fazendo alusão ao momento atual e à "exposição" do tema na mídia, Chaves (2008) utiliza o termo glamourização da adoção, referindo-se à adesão de celebridades a tal prática $^{1}$, o que tem contribuído ainda mais para a aparição do tema na mídia. Contudo, tal glamourização não traz consigo reflexões sobre o assunto, ou, pelo menos, elas ainda não andam no mesmo ritmo, ficando as reflexões comumente restritas às famílias adotivas e aos profissionais que as assistem, incluindo, ainda, os grupos de apoio à adoção existentes no país ${ }^{2}$.

O que a História nos mostra, por outro lado, é que a adoção não é uma prática pós-moderna. Conforme nos descreve Paiva (2004), os escritos bíblicos já mencionam casos envolvendo adoção de crianças, como a história de Moisés. Aproximadamente no ano 1250 a.C., por determinação do faraó, todas as crianças israelitas do sexo masculino deveriam ser mortas ao nascer. A mãe de um desses meninos decidiu colocá-lo em um cesto à beira do rio na esperança de que sobrevivesse. A criança, que recebeu o nome de Moisés, foi encontrada pela filha do faraó, que o adotou como filho. Futuramente esta criança veio a se tornar o herói do povo hebreu.

Autores como Paiva (2004) e Weber (1999), resgatando a adoção nas diferentes fases da história, afirmam que essa prática recebeu vários significados no decorrer dos tempos, desde religiosos até políticos, sendo valorizada ou não, conforme a cultura e o modo de pensar de determinada época. Durante a Antiguidade sua valorização esteve relacionada com a possibilidade de perpetuação do nome de uma família para aqueles que não tinham descendentes. Já na Idade Média, por influência da Igreja Católica, a adoção passa a não ser bem vista, tendo como justificativa o fato de que poderia influenciar o reconhecimento legal dos filhos adulterinos ou incestuosos. Ressurge novamente na Idade Moderna, agora já incluída no Código Civil. No que se refere especificamente ao nosso país, como se constituiu a história a respeito da temática da filiação adotiva e qual a repercussão para o cenário atual?

Em nossa experiência de quase 10 anos trabalhando em um juizado da infância e da juventude, acompanhando famílias adotivas, observamos que, embora a experiência da adoção seja singular para cada família, existem aspectos que são frequentemente observados, como a relação adoção e caridade; adoção e infertilidade; adoção e problemas de aprendizagem; além dos mitos e medos em relação à revelação da adoção para o filho.

Estes aspectos acabam por aproximar as famílias adotivas de diferentes profissionais, como os médicos, psicólogos, professores, 
que muitas vezes não tiveram oportunidades de refletir sobre a adoção, nem durante, nem após sua formação profissional. São especialistas de quem se espera opiniões fundamentadas cientificamente. Mas, na prática, o que acontece são opiniões de senso comum, muitas vezes carregadas de preconceitos, refletindo o desconhecimento a respeito da temática.

Em pesquisa realizada por Maux e Dutra (2009), entrevistando mulheres que adotaram uma criança, considerações feitas por médicos a respeito da decisão dessas mulheres em relação à adoção, ajudam a exemplificar esta questão. Os resultados apresentados pelas autoras mostram que alguns daqueles profissionais de saúde faziam referências a decisão das mulheres pela adoção usando expressões que relacionam o ato de adotar como "loucura", de que o filho adotivo traria problemas no futuro, ou de que a mãe adotiva não poderia ter os benefícios concedidos às mães biológicas, como a licença maternidade, porque não havia sido ela quem teria gerado e parido aquele filho. Para as mães participantes da pesquisa, tais comentários foram sentidos como uma agressão a sua capacidade de maternar, como se, o fato de elas não terem gerado os filhos, não as fizesse capazes de exercer o papel materno, qual seja, cuidar, proteger e educar. Ao mesmo tempo, a indignação serviu como um desafio, fazendo com que elas, através do exercício da maternagem, orgulhem-se em falar sobre ser mãe por adoção, enfatizando não haver diferença entre os cuidados que dedicam aos filhos e o que observam em outras mães que geraram seus próprios filhos. Uma das entrevistadas, funcionária de uma Universidade, em suas colocações, expressa sua indignação com o fato de ter sido um médico da própria instituição educacional aquele que fez comentários preconceituosos em relação a adoção, ressaltando que outros médicos, que não circulam no meio acadêmico (local, espera-se, de produção de saberes), se mostraram mais acolhedores que aquele de quem ela esperava mais acolhimento.

Este artigo é resultado de uma pesquisa bibliográfica sobre a temática da adoção, pesquisa esta motivada pelos nossos questionamentos, dúvidas e curiosidades surgidas a partir da prática com a temática em tela. Desenvolvemos reflexões sobre a prática da adoção no cenário nacional, objetivando conhecer a maneira como a adoção foi vista em diferentes contextos da história do nosso país e suas repercussões no cenário atual. O nosso objetivo é que o texto sirva como leitura introdutória ao tema da adoção para as pessoas que se interessam pelo assunto, mas não têm conhecimento científico a respeito, ou como contribuição para aqueles que já transitam, academicamente ou não, pela temática da filiação adotiva. Esperamos poder contribuir, tanto para as pessoas que vivenciam a adoção, seja por serem ou terem um filho adotivo, como para os profissionais que assistem famílias adotivas, ou que possam vir a 
assisti-las, para que adquiram mais conhecimento sobre a temática e, a partir de então, reflitam e se aprofundem na complexidade que envolve os relacionamentos afetivos.

\section{A prática da adoção no cenário nacional}

A história da adoção tem um percurso extenso no Brasil e se faz presente desde a época da colonização. A princípio esteve relacionada com caridade, em que os mais ricos prestavam assistência aos mais pobres. Era comum haver no interior da casa das pessoas abastadas filhos de terceiros, chamados "filhos de criação". A situação deste no interior da família não era formalizada, servindo sua permanência como oportunidade de se possuir mão-de-obra gratuita (PAIVA, 2004) e, ao mesmo tempo, prestar auxílio aos mais necessitados, conforme pregava a Igreja. Portanto, foi através da possibilidade de trabalhadores baratos e da caridade cristã, que a prática da adoção foi construída no país. Já se percebe, então, que não havia um interesse genuíno de cuidado pela criança necessitada ou abandonada. Este "filho" ocupava um lugar diferenciado, sendo também singular a maneira como era tratado, sempre de forma distinta, comumente inferior, aos filhos biológicos. Seria algo semelhante a dormir junto com os demais membros da família e não no espaço reservado aos empregados, contudo, não possuir um quarto ou uma cama próprios.

Tal herança cultural contribuiu significativamente para que, até os dias de hoje, esta forma de filiação seja impregnada por mitos e preconceitos. Para termos uma idéia, segundo Weber (2001), a prática ilegal de registrar como filho uma criança nascida de outra pessoa sem passar pelos trâmites legais, ou seja, o registro feito diretamente em cartório, conhecida como adoção à brasileira, até os anos 80 do século XX, constituía cerca de $90 \%$ das adoções realizadas no país. Desta forma procurava-se, dentre outras razões, esconder a adoção, como se esta fosse motivo de vergonha e humilhação. Hoje em dia, embora a lei proíba tal prática, ainda encontramos casos de pessoas que realizaram uma adoção à brasileira e justificam que o fizeram por não saber que era ilegal e porque na época em que o avô, o pai, ou algum conhecido realizou uma adoção, era assim que se fazia. Em uma pesquisa realizada pela Associação dos Magistrados Brasileiros, em 2008, apenas 35\% dos respondentes afirmaram que, caso desejassem adotar, buscariam uma criança através das Varas de Infância e Juventude, enquanto $66,1 \%$ recorreriam aos hospitais/maternidades ou abrigos, confirmando que a maioria dos brasileiros não sabe por onde se inicia um processo de adoção legal.

A primeira vez que a adoção apareceu em nossa legislação foi em 1828, e tinha como função solucionar o problema dos casais sem filhos. (PAIVA, 2004). Esta foi, também, outra influência cultural de 
nossos antepassados: associar adoção como recurso para casais sem filhos, como se esta forma de filiação se prestasse apenas para solucionar o caso do casal infértil.

Mudanças legais foram ocorrendo desde então, até culminar com o Estatuto da Criança e do Adolescente (E.C.A), Lei 8.069, de 13 de julho de 1990, que há quase 20 anos regulamentou a prática da adoção no Brasil (mas que sofreu algumas mudanças a partir de novembro de 2009, com a lei 12.010/09, também chamada de Nova lei da Adoção), e que coloca como prioridade a garantia, às crianças e adolescentes, dos seus direitos, dentre os quais a convivência familiar.

O nosso Código Civil de 1916 (Lei 3071/16) foi um marco importante para a legislação brasileira, posto que aglutinou leis, contribuindo de forma relevante para a adoção porque, conforme Weber (2006), a referência a este tema aparecia de forma escassa nos textos jurídicos anteriores. De acordo com aquela lei, além de a adoção ser permitida apenas para os casais sem filhos, poderia ser revogada e o adotando não perdia o vínculo com a família biológica. Em 1957 (Lei 3.133/57) aconteceram algumas modificações interessantes em relação a adoção. As pessoas que já possuíam filhos poderiam adotar, mas, nestes casos, o filho adotivo não teria direito a herança.

A partir da legislação de 1965 (Lei 4.655), além das pessoas casadas, as viúvas e os desquitados também passaram a ter direito de adotar. Ou seja, há pouco mais de 40 anos somente casais poderiam vir a ter filhos adotivos. A lei de 1965 também trouxe como mudança significativa para o instituto da adoção: a chamada legitimação adotiva, que se caracterizava pela possibilidade de o filho por adoção ter praticamente os mesmos direitos legais do filho biológico (com exceção dos direitos sucessórios) e, automaticamente, interromper os vínculos com a família biológica, o que significava a irrevogabilidade do ato de adotar. Entretanto, como bem nos lembra Paiva (2004), a adoção somente seria irrevogável nos casos envolvendo crianças abandonadas até os seus 7 anos de idade ou aquelas cuja identidade dos pais era desconhecida.

A Lei 6.697/79, conhecida como Código de Menores, pois fim a legitimação adotiva, estabelecendo duas formas de adoção: a adoção simples a adoção plena, onde a primeira tratava da situação de crianças maiores de sete anos até adolescentes menores de 18 anos e que estivessem em situação irregular. Já na adoção plena o adotando, criança até os 7 anos de idade, passava a condição de filho, sendo o ato irrevogável.

Foi somente com a legislação de 1988 que a lei passou a tratar de maneira igualitária todos os filhos, havidos ou não do casamento, ou por adoção. E é este pressuposto legal que alicerça O E.C.A, que aboliu a adoção simples, ampliando os benefícios da adoção plena a todos os menores de 18 anos de idade, garantindo a permanência 
irrevogável no seio da família adotivo, sob a condição de filho, assegurando-lhes os mesmos direitos dos filhos biológicos, rompendo os vínculos de parentesco com a família de origem. Ademais, estende o direito de adotar à todas as pessoas maiores de 18 anos de idade, independente do seu estado civil ou de suas condições de fertilidade.

Em agosto deste ano de 2009 foi sancionada a lei 12.010/09, que passou a vigorar em novembro do mesmo ano, e traz novas questões a respeito da prática da adoção em nosso país. Tanto para o E.C.A quanto para a nova lei da adoção não há diferenciação legal entre os filhos de um casal, independente de serem eles adotivos ou biológicos.

As leis nacionais anteriores ao E.C.A privilegiavam os filhos biológicos em detrimento dos adotivos, valorizando o chamado laço de sangue, dando ao fator biológico um status superior. A recente lei 12.010/09, em seu artigo 25, apresenta o conceito de família extensa ou família ampliada, que seria composta por parentes próximos da criança e que teriam prioridade em sua adoção caso ela não ficasse sob os cuidados dos pais. Aqui temos um terceiro fator histórico que colaborou para uma cultura de adoção como filiação de segunda categoria, discriminada. Observa-se que todas as leis referentes a adoção, e que foram anteriores ao E.C.A, há sempre uma prioridade à família biológica, seja considerando a adoção possível somente quando as pessoas não pudessem gerar filhos; ou considerando o filho adotivo inferior ao biológico (que poderia perder seu espaço dentro da família, para as adoções revogáveis), ou, ainda, negandoIhe o direito à herança deixada pelos pais quando havia filhos biológicos.

Tal fato também justifica a característica, ainda bastante presente nas família adotivas, que é o desejo de que a adoção seja um assunto sigiloso e que, muitas vezes, é de conhecimento apenas dos membros da família, não sendo divulgado, nem entre os parentes, muito menos para as pessoas conhecidas, uma espécie de segredo de família. A prática de atendimento às famílias adotivas tem mostrado que, para muitos pais, ainda há um constrangimento em falar para outras pessoas sobre a maneira como o filho chegou à família. Um caso interessante que ajuda a ilustrar a questão é quando a mãe adotiva registra fotos "grávidas", fazendo uso de travesseiros ou outro material que, quando colocado por baixo da roupa, insinua uma barriga, com o intuito de registrar, no álbum de fotografia do filho, sua gestação. Tanto não se deveria falar sobre o assunto porque ele remetia ao fato de que a criança não fazia parte, biologicamente, da família e, dessa forma, seria inferior aos demais membros da constituição familiar, quanto se impunha evitar os olhares discriminatórios da sociedade. Só partiriam para a adoção, então, aqueles que não fossem capazes de gerar seus próprios filhos, mas que desejavam constituir uma família. Tal prática contribuiu para 
consolidar a relação adoção e infertilidade, crença que permanece até os dias atuais. Estudos na área (MALDONADO, 1997; PAIVA, 2004; REPPOLD; HUTZ, 2003; SCHETINNI FILHO, 1998b; VIEIRA, 2004; WEBER, 1999; WEBER, 2001) têm mostrado que a infertilidade configura-se, ainda hoje, como o principal motivo que leva casais a procurar os Juizados da Infância e da Juventude buscando, através da adoção de uma criança/ adolescente, construir uma família.

Em uma pesquisa realizada por weber (2006) envolvendo famílias de vários estados do país, $50 \%$ dos entrevistados trouxeram como motivação para a adoção o fato de não terem os próprios filhos (incluindo-se aí aqueles que desejavam escolher o sexo da criança ou problemas de infertilidade para gerar o segundo filho). Para aqueles que não possuíam filhos biológicos, a infertilidade foi apresentada como motivação por mais de $80 \%$ dos respondentes. Paiva (2004) apresenta os dados de um levantamento realizado na Comarca de Osasco/SP, mostrando que $76,2 \%$ dos pretendentes à adoção naquela Comarca apresentam como motivação à adoção a incapacidade para ter filhos biológicos. E, embora nossa prática tenha mostrado um crescente aumento de pessoas solteiras, casais em segunda união e que já possuem filhos da união anterior, bem como de pessoas que já tiveram filhos, mas desejam adotar, a questão da infertilidade ainda é a justificativa mais relatada pelos candidatos à adoção. Em uma pesquisa interna realizada pela $2^{\text {a }}$ Vara da Infância e da Juventude da cidade do Natal, no ano de $200980 \%$ dos pedidos de inscrição de pessoas pretendentes à adoção foi formulado por casais, dos quais $79,2 \%$ justificaram problemas de infertilidade como motivação para adotar uma criança ou adolescente. $E$, no que diz respeito aos pedidos formulados por uma só pessoa (solteiras, divorciadas, viúvas), entre os anos 2000 e 2009 houve um aumento de $7,5 \%$, passando de $12,5 \%$ para $20 \%$ nestes últimos 9 anos.

Percebemos, com o E.C.A, que o objetivo da adoção passa a ser garantir ao menor de idade o direito de ser criado no interior de uma família e não o de resolver, por exemplo, o problema de casais sem filhos. Entretanto, pensamos que embora o E.C.A, e mais recentemente a lei 12.010/09, busque tratar a criança, sem supervalorizar o aspecto biológico, este ainda é visto como superior, pois, de acordo com o Art. 19 do E.C.A, é um direito da criança permanecer no interior de sua família biológica, sendo a adoção uma decisão excepcional, tomada somente quando se esgotam as possibilidades de continuidade da criança no seio da família. Percebemos que a nova lei reitera aquela que a precedeu, a qual já apresentava a preferência dada à família biológica em detrimento de outras famílias. No Art. $28 \S 3^{\circ}$ a lei aponta a valorização dos laços de afeto, contudo, mais uma vez, o subestima perante o laço de consanguinidade. Diz o texto legal que, ao ser apreciada a solicitação de alguém para adotar uma criança ou adolescente, o juiz levará em 
consideração o grau de parentesco e a relação afetiva entre quem está sendo adotado e quem está querendo adotar. Novamente vemos uma busca pela permanência da criança no seio da família com quem possui vínculos genéticos antes de ser cogitada a possibilidade de ela ser encaminhada para uma família substituta fora do contexto biológico. Isto é, percebe-se claramente uma posição que privilegia a dimensão biológica da família, deixando a colocação em família substituta em plano secundário. Embora também leve em consideração os vínculos afetivos, a lei recomenda observar o grau de parentesco primeiro.

Acrescentamos, ainda, outro fator, qual seja, a carência de trabalhos científicos sobre a temática. $O$ primeiro trabalho acadêmico na área de psicologia, sobre o assunto, de acordo com Weber (1999), data de meados da década de 80 do século XX. Embora se constate um aumento de publicações sobre o tema, esta ainda se mostra uma produção tímida, principalmente se levarmos em consideração o tempo de existência dessa forma de constituição familiar no país. Segundo estatística da Biblioteca Digital Brasileira de Teses e dissertações (BDTD) ${ }^{3}$, dos anos 2000 até 2006, há 19 trabalhos (entre teses e dissertações das área de psicologia, direito, antropologia, serviço social, letras e sociologia) publicadas sobre a temática da adoção, enquanto praticamente a mesma quantidade, um total de 18 trabalhos, foi publicado entre 2007 e fevereiro de 2009. Especificamente na área de psicologia, enquanto até 2006 foram um total de 9 trabalhos, entre 2007 e fevereiro de 2009 somam-se a mesma quantidade, confirmando o crescimento de publicações sobre o tema.

Quando somos convidadas, como psicólogas judiciárias responsáveis pelo acompanhamento de famílias adotivas na cidade do Natal/RN, para participar de algum evento acadêmico sobre o tema da adoção (mesas redondas, debates, palestras), observamos que muitas questões e comentários trazidos, tanto pelos estudantes como pelos professores, carregam uma herança cultural muito forte, sendo comentários relacionados tanto a questões legais (irrevogabilidade, perda de vínculos com a família biológica) quanto por visões preconceituosas em relação ao ato de adotar, muitas vezes semelhantes aos comentários feitos pelos médicos que assistiram as mães participantes da pesquisa de Maux e Dutra (2009), descrito mais acima.

Assim, pensamos que, a falta de uma discussão acadêmica, levantando reflexões e questionamentos a respeito da adoção de crianças e adolescentes, pode ser entendida como um dos aspectos que contribuíram para a permanência de valores preconceituosos e pouco científicos a respeito da temática. 


\section{A influência dos laços de sangue e suas consequências para a adoção}

A cultura dos laços de sangue, termo utilizado por Weber (1999) para designar a construção de um modelo familiar baseado nos laços de consanguinidade, surge a partir do modelo de família patriarcal formado por pai, mãe e filhos. O vínculo biológico passou a ser valorizado e apontado como superior a qualquer outro. Ariès (2006) explica que no século XVII desenvolveu-se por diversos países da Europa o costume de se valorizar o sentimento de família formada por pais e filhos, sendo exaltada a comparação das semelhanças físicas, ou seja, biológicas, entre os genitores e seus descendentes. Embora houvesse uma valorização do laço familiar que unia aquelas pessoas, não deixava de haver uma busca pela semelhança com os laços biológicos porque a criança seria a representação, a imagem viva, dos seus pais. E, como ser a imagem do pai, ou da mãe, sem se assemelhar a eles biologicamente?

A nossa herança cultural européia ainda se faz presente em nosso dia-a-dia. Valorizamos os nossos genes e os consideramos superiores aos dos demais. Shaffer (2008) e Bee (2003) relatam a conclusão de diversos estudos, sobretudo na área da genética comportamental, concluindo que tanto os genes quanto a estimulação ambiental são fundamentais para o desenvolvimento humano e, desta forma, atestar o comportamento inadequado de uma pessoa pela sua "má semente", ou seja, a partir de sua herança genética, é fazer uma reflexão muito simplista a respeito da complexidade de que é o ser humano. Nas palavras de Shaffer

Sim, os genes podem influenciar nossas reações à
estimulação ambiental e, em última instância, nossa conduta
social, mas dificilmente determinam nossa conduta. (...) a
natureza precisa da educação para expressar seu
comportamento, e a educação sempre age sobre a natureza.
Não existiria desenvolvimento algum sem a contribuição
contínua de ambas. (SHAFFER, 2008, p. 621)

Assim, não há como desconsiderarmos a relevância dos genes, ou seja, do sangue no desenvolvimento de uma pessoa, mas esta não é a única nem a principal determinante que explicaria a personalidade de uma pessoa. O sangue atesta o pertencimento entre as pessoas, é uma relação eterna. Os nossos genes ou, popularmente, o nosso sangue, faz parte da ambição humana de perpetuação. É uma forma de continuarmos existindo após a nossa morte, através dos genes que deixamos como herança nos nossos descendentes. É uma espécie de garantia física de que iremos permanecer. Contudo, não é incomum generalizarmos a herança biológica deixada, atrelando comportamentos, atitudes e características de personalidade ao sangue. Luna (2005) citando diversos depoimentos de pessoas a 
respeito de suas impressões sobre adoção confirma a importância dada ao fator genético, sendo esta uma das justificativas que algumas pessoas até expressam quando justificam o motivo pela qual não adotariam uma criança.

Uma pesquisa realizada por Berthoud (1997) também traz resultados similares, concluindo aquela autora que o preconceito mais grave da população em geral sobre a adoção está relacionado ao desconhecimento sobre a herança genética. Para os participantes de sua pesquisa, adotar poderia ser um risco, já que haveria a possibilidade de adotar alguém com 'sangue ruim', ou seja, com traços negativos de comportamento e personalidade.

O sangue do outro me é desconhecido e, consequentemente, as características que esse outro possui. E o que é desconhecido fomenta fantasias, muitas vezes ameaçadoras. Assim, não é incomum os pais adotivos culparem os pais biológicos (o 'sangue ruim' ou inferior) pelas dificuldades ou quaisquer outras questões vistas como negativas na vida do filho. Por outro lado, logo esquecem os laços de sangue entre o filho e os pais biológicos deste quando acontecem as vitórias. Nossa prática atendendo famílias adotivas tem mostrado que há pais adotivos que se mostram muito orgulhosos da educação dada ao filho quando este consegue êxito, normalmente relacionado às questões de ensino-aprendizagem ou sucesso esportivo.

Também a partir da sua prática atendendo famílias adotivas, Schetinni Filho (1998a) observou comportamentos que se assemelham as nossas observações. Aquele autor afirma que, quando o filho adotivo atende às expectativas dos pais e parentes a família adotiva não faz nenhum comentário a respeito. Ao contrário, ao primeiro sinal de dificuldade que a criança possa passar, há famílias que tendem a atribuir à adoção, ao sangue que a criança carrega, a responsabilidade pelo fato.

A questão genética assegura aos pais biológicos a certeza de que são pais. Gerar um filho significa, além da perpetuação biológica, uma espécie de apropriação desse filho. "Os pais biológicos sabem desde o início que a criança é incondicionalmente sua" afirma Levinzon (2004, p. 26). Os pais adotivos, por outro lado, precisam que a sociedade, na figura da justiça, Ihes garanta essa posse. “(...) os pais adotivos necessitam da ação de um órgão governamental (no Brasil, os Juizados da Infância e da Juventude), de uma agência, ou ainda de pessoas desconhecidas ligadas ao mundo da adoção" (LEVINZON, 2004, p. 26) para se sentirem seguramente pais daquele filho.

Autores como Benghozi e Féres-Carneiro (2001) explicam que quando acontece a união conjugal entre duas pessoas, elas já carregam, além de sua base ou ascendência genealógica, uma descendência em potencial. Em outras palavras, antes mesmo da chegada dos filhos, estes já ocupam um espaço emocional na vida 
dos pais. Espaço que tem sua base na ascendência dos pais, ou seja, nos laços de sangue. Quando o filho nasce e concretamente passa a fazer parte da família, as relações afetivas que os pais irão desenvolver com ele estarão baseadas na cultura familiar e na garantia de que aquele filho pertence à família. A criança será estimulada a desenvolver comportamentos característicos daquele núcleo familiar e a satisfazer os desejos dos pais. O fato de ela carregar o sangue da família, já faz dela um de seus membros. Quando ela corresponde aos estímulos recebidos, confirma ainda mais fazer parte da família. Entretanto, quando surgem comportamentos ditos inadequados ou estranhos àquela ascendência, o filho real passa a se distanciar do filho desejado e; caso os pais não aceitem a subjetividade deste filho, seu modo de ser, poderá acontecer questionamentos quanto à herança da criança. A quem ele (ou ela) puxou? Resgata-se toda uma árvore genealógica na busca por justificar aquele comportamento "errado", embora a pertença à família não seja questionada. Mas, e quando o filho surge na vida dos pais a partir da adoção? O espaço emocional na vida dos pais também acontece antes de sua chegada, e quanto mais distante este filho estiver do filho idealizado, maiores serão as chances de os pais adotivos justificarem a herança genética da criança ao seu modo de ser, culpando os pais biológicos pelo que está acontecendo no desenvolvimento do filho. Caso a família não esteja aberta para aceitar aquele membro com a sua subjetividade, haverá constantemente uma busca do filho para garantir sua pertença na família, podendo levá-lo a construção de uma subjetividade muito semelhante ao conceito de Carl Rogers para incongruência, ou seja, quando os comportamentos não estão em acordo com os sentimentos reais obtidos a partir das experiências vividas. Por exemplo, a criança não gosta de ler, mas os pais relatam que todos na família são fascinados por leitura e, portanto, ela também deve ser. Para agradálos, quando ela ganha um livro, embora fique descontente, demonstra alegria e gratidão. Com o passar do tempo ela se distancia dos seus reais sentimentos, passando a viver de forma incongruente. Segundo Wegar (2000) esta cultura que privilegia o aspecto biológico exerce influência na sociedade de forma geral, incluindo, além das famílias, os profissionais que trabalham com a adoção de crianças/adolescentes e os pesquisadores da temática. I sso contribuiu para que muitas pesquisas (BORDERS; BLACK; PASLEY, 1988; SANTOS, 1998) tenham sido e ainda sejam produzidas relacionando a adoção com questões da saúde mental, posto que os filhos adotivos, quando apresentavam quaisquer dificuldades em seu desenvolvimento, estas eram logo atribuídas pelos profissionais a uma questão genética, isentando os pais adotivos de qualquer responsabilidade. Berthoud (1997) explica que as primeiras pesquisas com filhos adotivos tinham como população pesquisada os pacientes 
de clínicas de psicologia ou psiquiatria, difundindo a ideia de que a adoção estava relacionada com problemas mentais, de delinquência e de aprendizagem escolar.

É comum entre as pessoas que adotam, a preferência por crianças de pouca idade e com características físicas próximas às suas (MALDONADO, 1997; WEBER, 1999). De acordo com Vieira (2004) essa preferência seria uma clara tentativa de reproduzir da maneira mais fiel possível a experiência que teriam aquelas pessoas caso tivessem elas mesmas concebido o filho, além de diminuir os riscos de se defrontar com a curiosidade indiscreta das pessoas que, encontrando pouca semelhança física entre pais e filho, poderiam questionar a filiação daquele, mostrando quão forte é a influência cultural, que privilegia os vínculos genéticos. E isso causa impacto negativo em algumas famílias adotivas, que acabam por se sentirem menores, como uma subcategoria. Assim, num efeito bola de neve, a adoção permanece sendo um dos segredos das famílias e estas, por mais que valorizem os laços de afeto, buscam, incessantemente, a imitação da biologia.

Embora não possamos negar a existência e atuação dos fatores biológicos na história de desenvolvimento de cada um de nós, os depoimentos de pais adotivos, muitos destes ilustrados no livro Filhos adotivos, pais adotados: depoimentos e histórias de escolhas, mostram que a aprendizagem do amor pode ser mais importante (WEBER, 2007). Não podemos esquecer, contudo, que o filho adotivo não tem garantido, diante da família adotiva, seu certificado de pertença a mesma (ou seja, o sangue), precisando garantir, a partir das relações afetivas desenvolvidas com os familiares, que também é membro daquele núcleo. Ademais, em especial para os profissionais que assistem famílias por adoção, considerar que a cultura influencia na maneira com que aqueles que adotam pensam seus filhos, e que estes já existem na vida emocional dos pais antes mesmo de sua chegada, são pontos fundamentais para que possam ser trabalhados junto àqueles que desejam ser pais por adoção, visando possibilitar reflexões a respeito dos diversos aspectos que envolvem a filiação adotiva, diminuindo as possibilidades de conflitos ou insucesso da adoção.

\section{A origem negada, o medo do abandono e o segredo sobre a adoção}

A cultura que valoriza os laços consanguíneos em detrimento dos laços afetivos também está relacionada a outras questões fundamentais na reflexão sobre a adoção: o medo dos pais adotivos de serem abandonados pelo filho e a dificuldade para revelar ao filho sobre sua história de vida. Os pais, cujo filho é adotivo, muitas vezes se sentem inseguros sobre os vínculos afetivos desenvolvidos entre eles, fantasiando que um dia o filho deseje conhecer os pais 
biológicos e, caso esse encontro venha a acontecer, o 'sangue' fale mais alto e ele opte por ficar com a família "de sangue". Para Schetinni Filho (1998a), tal insegurança decorre da interpretação que os pais adotivos fazem da adoção como uma espécie de interferência no fluxo natural da vida daquele filho, algo como se seu lugar fosse ao lado dos pais biológicos. Para ilustrar esta questão trazemos um exemplo que acompanhamos, onde a mãe adotiva, temendo que o filho pudesse trocá-la pelos pais biológicos, proibiu toda a família de falar no assunto com a criança. Esta, com a idade aproximada de 10 anos, ao voltar da escola acompanhada pela mãe adotiva, foi surpreendida por uma mulher, que se apresentou como sendo sua mãe, a tomou pela mão e a levou embora, deixando para traz uma mãe adotiva surpresa e paralisada diante da situação. A referida senhora justifica seu entorpecimento diante da cena de ver seu filho sendo levado por outra mulher dizendo que nada poderia fazer porque "ela era a mãe dele".

A fantasia de que o filho adotivo possa "trocar" os pais adotivos pelos biológicos também pode dificultar àqueles a colocação de limites e regras. Eles podem ter receio de que o filho fique aborrecido e decida ir embora, ou que o filho pense que não é por eles amado. E a falta de autoridade pode gerar, como consequência, crianças desobedientes e sem limites, que lotam os consultórios psicológicos e estimulam as estatísticas de que filho adotivo é sinônimo de criança problemática e adolescente rebelde. Nesses casos percebemos que não é a adoção, mas a falta de segurança dos pais no vínculo afetivo construído com o filho, o medo de não ser o pai real ou "de direito" que gera as dificuldades futuras.

Este receio de ser rejeitado pelo filho é o que leva muitos pais a decidirem não contar para o filho sobre a história de sua adoção. As consequências práticas dessa decisão são a apresentação de histórias fantasiosas, no intuito de manter o segredo sobre a adoção, o que significa a criação de frequentes mentiras criadas para preencher as lacunas que a não revelação da adoção traz.

Quando acontece de um dos pais (ou ambos) ser infértil e apresentar dificuldades para assumir sua infertilidade, esconder a adoção pode ser entendido como uma busca para calar em todos (até em si mesmo) a impossibilidade de gerar. De acordo com Paiva (2004), casais que não conseguem elaborar o luto pela infertilidade podem encontrar maiores dificuldades para revelar ao filho sobre sua história de vida, pois implica reavivar suas incapacidades e frustrações.

Berthoud (1997), estudando o desenvolvimento do vínculo afetivo na díade mãe-filho adotivo concluiu, sobre casais inférteis, que aqueles que conseguiram elaborar os conflitos da infertilidade, desenvolveram vínculo afetivo positivo com a criança adotada, além de um sentimento de paternidade/maternidade fortemente estabelecido. Já aqueles para quem a elaboração dos conflitos a respeito da 
infertilidade não foi bem resolvido, o desenvolvimento do vínculo com o filho adotivo ficou prejudicado.

$\mathrm{Na}$ literatura nacional sobre a temática da adoção, autores como Maldonado (1997), Berthoud (1997) e Paiva (2004) concluem que o fato de serem "bons" ou "maus" pais independe da condição de serem pais biológicos ou adotivos; mas depende, sim, da motivação que leva homens e mulheres a buscar um filho. Os adjetivos bom e mau são utilizados em referência a forma popular de se definir pais ou cuidadores. Quando eles se mostram protetores e amorosos com os filhos, assistindo-os com carinho e firmeza na colocação de limites e regras, diz-se que são bons pais. Quando se mostram desatenciosos, rudes, negligentes, apáticos ou agressivos, não exercendo os papéis parentais de forma a possibilitar à criança desenvolver-se física e emocionalmente saudável, considera-se maus pais. E exercer o papel de cuidador em relação a uma criança independe de ter com ela relações de consanguinidade. Schetinni Filho (1998a) esclarece a questão quando considera que os filhos (sejam biológicos ou adotivos), precisam sempre ser adotados - no sentido do afeto, do cuidado. "É o afeto dedicado a uma criança que faz dela um filho e constrói em nós a postura de pais" (SCHETINNI FILHO, 1998a, p. 48).

No que concerne ao filho adotivo conhecer sua história de vida, a opinião unânime, seja entre os teóricos da temática da adoção, ou entre aqueles profissionais que atendem famílias adotivas, é aquela que valoriza a verdade, sempre. Concordamos com Levinzon (2004) quando ela comenta que a história da criança deve fazer parte das conversas familiares, de maneira que não haja segredo a ser revelado, mas uma situação natural e espontânea na memória daquele filho. "Quando a criança tem a sensação de "sempre ter sabido", evita-se o caráter imponente e traumático do desvelamento de um segredo". (LEVINZON, 2004, p. 53).

\section{Considerações finais}

Embora a adoção seja uma prática frequente em nossa sociedade desde a colonização, ainda está encoberta por um véu de insegurança quanto a sua legitimidade. O grande poder atribuído aos laços de sangue, considerados indissolúveis, leva muitas pessoas a valorizar os pais biológicos, percebidos como "verdadeiros" $e$, consequentemente, a família adotiva seria a "falsa" ou ilegítima. Então, a qualquer tempo que o reencontro entre filho adotivo e família biológica acontecer, o 'sangue' provará sua força e os pais adotivos serão preteridos em relação à família biológica. Por outro lado, ainda é muito arraigada a idéia de que os filhos adotivos podem ser mais problemáticos que os biológicos, porque trazem em sua carga genética herança de distúrbios, tanto físicos quanto de conduta. Assim, a adoção seria uma filiação de segunda categoria, 
seja por ser uma "imitação da família real", seja por ter em seu núcleo uma pessoa com índole duvidosa. Esconder a adoção, seja do filho, seja da sociedade de forma geral, teria, portanto, motivação relacionada aos medos (do abandono, do preconceito, da rejeição) e a inaptidão dos pais adotivos para lidar com suas limitações pessoais.

Acreditamos que reflexões sobre essa temática devam ultrapassar os limites do núcleo familiar - nos casos de uma família por adoção percorrendo as discussões e produções científicas e culturais, possibilitando, assim, a revisão de valores e, quem sabe, a promoção de mudanças que visem construir uma nova cultura da adoção, pautada em atitudes como o respeito ao outro e à sua singularidade.

\section{Referências Bibliográficas}

ARIĖS, P. História social da criança e da família. 2 ed. Rio de Janeiro: LTC, 2006.

Associação dos Magistrados do Brasil (AMB). Percepção da população brasileira sobre a adoção. Brasília/DF, 2008. Disponível

em:

http://www.amb.com.br/mudeumdestino/docs/pesquisa_adocao.pdf

Acesso em: 08 dez.2009.

$\mathrm{BEE}, \mathrm{H}$. A criança em desenvolvimento. 9a Ed. Porto Alegre: Artmed, 2003.

BENGHOZI, P. ; FÉRES-CARNEIRO, T. Laço frátrio e continente frátrio como sustentação do laço genealógico. In: FÉRES-CARNEIRO, T. (Org). Casamento e família: do social à clínica. Rio de Janeiro: NAU, 2001.

BERTHOUD, C. M. E. Filhos do coração. São Paulo: Cabral Editora Universitária, 1997.

BORDERS, L. D.; BLACK, L. K.; PASLEY; B. K. Are adoption children and their parents at greater risk for negative outcomes?. Family Relations. v. 47, n. 3, p. 237-241. Disponível em: http://links.jstor.org./sici?sici $=0197$ -

6664\% 28199807\% 2947\% 3A3\% 3C237\% 3AAACATP\% 3E2. 0.CO\% 3b2Data de acesso: 02 jun.2007.

BRASIL. Lei Federal №. 8069, de 13 de julho de 1990. ECA Estatuto da Criança e do Adolescente. Brasília, 1990. Disponível em: http://www. planalto.gov.br/ccivil/LEIS/L8069.htm. Acesso em: 07 outubro 2009.

BRASIL. Lei Federal № 12.010/09, de 03 de agosto de 2009. Nova Lei Nacional da Adoção. Brasília, 2009. Disponível em: http://www.planalto.gov.br/ccivil 03/_Ato2007-

2010/2009/Lei/L12010.htm. Acesso em: 07 outubro 2009.

CHAVES, V. P. Adoção e homossexualidade. In:

Adoção: um direito de todos e todas. Conselho Federal de Psicologia (CFP), Brasília, 2008. 
LEVINZON, G. K. Adoção. São Paulo: Casa do Psicólogo. Coleção clínica psicanalítica, 2004.

LUNA, N. Novas Tecnologias Reprodutivas: natureza e cultura em Redefinição. Campos - Revista de Antropologia Social, América do Sul, 5507 2005. Paraná, v. 5, n.2, p. 127-156, 2004. Disponível em:

http://ojs.c3sl.ufpr.br/ojs2/index.php/campos/article/view/1624/136 6 >. Acesso em: 26 de dez. 2009.

MALDONADO, M. T. Os caminhos do coração: pais e filhos adotivos. São Paulo: Saraiva, 1997.

MAUX, A. A. B.; DUTRA, E. Do útero à adoção: a experiência de mulheres férteis que adotaram uma criança. Estudos de psicologia. Natal, v. 14, n.2, p. 113-121, maio-agosto 2009.

PAIVA, L. D. Adoção: significado e possibilidades. São Paulo: Casa do Psicólogo, 2004.

REPPOLD, C. T.; HUTZ, C. S. Reflexão social, controle percebido e motivações à adoção: características psicossociais das mães adotivas. Estudos de psicologia. Natal, v. 8, n.1, p. 25-36, abril 2003.

SANTOS, N. P. S. As possibilidades de satisfação na adoção. Psicologia, teoria e pesquisa. Brasília, v. 4, n. 2, p. 113-128, maio 1998.

SCHETINNI FILHO, L. Compreendendo o filho adotivo. Recife: Bagaço, 1998a.

$\overline{1} \overline{9} \overline{9} \overline{\mathrm{b}}$.

L. Compreendendo os pais adotivos. Recife: Bagaço,

SHAFFER, D. R. Psicologia do desenvolvimento: infância e adolescência. São Paulo: Cengage Learning, 2008.

VIEIRA, J. M. Os filhos que escolhemos: discursos e práticas da adoção em camadas médias. 2004. 214 f. Dissertação. (Mestrado em Antropologia Social), Universidade Estadual de Campinas, São Paulo.

WEBER, L. N. D. Aspectos psicológicos da adoção. Curitiba: Juruá, 1999.

Pais e filhos por adoção no Brasil: características, expectativas e sentimentos. Curitiba: Editora: Juruá, 2001.

(Org.) Filhos adotivos, pais adotados: depoimentos e histórias de escolhas. Curitiba: Gráfica Capital, 2007.

WEGAR, K. Adoption, family ideology, and social stigma: bias in community attitudes, adoption research, and practice. Family Relations, v. 49, n. 4, p. 363-370, October 2000. Disponível em: <http://www.apa.org/psycinfo/>. Acesso em: 12 jun. 2007.

\section{Endereço para correspondência}

Ana Andréa Barbosa Maux

R. Dr. Lauro Pinto, 315, 2ำ andar, 2a Vara da Infância e da Juventude, Lagoa Nova, CEP 59.064-250, Natal, RN, Brasil. 
Endereço eletrônico: anamaux@tjrn.jus.br

Elza Dutra

Universidade Federal do Rio Grande do Norte, Centro de Ciências Humanas Letras e Artes, Departamento de Psicologia, s/n, Lagoa Nova, CEP 59075-970, Natal, RN, Brasil.

Endereço eletrônico: elza_dutra@hotmail.com

Recebido em: 08/10/2009

Aceito para publicação em: 07/01/2010

Acompanhamento do processo editorial: Ana Maria Lopez Calvo de Feijoo

\section{Notas}

* Mestre

** Doutora

${ }^{1}$ Dentre as celebridades internacionais destacamos a cantora Madonna e os atores Brad Pitt e Angelina Jolie; ou, brasileiros, como a cantora Elba Ramalho e o ator Marcelo Antony.

${ }^{2}$ Destacamos a relevância dos Encontros Nacionais de Apoio à Adoção (ENAPAs), promovidos pelos Grupos de Apoio e que se realizam anualmente durante o mês de maio.

${ }^{3} \mathrm{~A}$ BDTD é um programa digital que estimula o registro e a publicação de teses e dissertações existentes nas instituições de ensino e pesquisa brasileiras em meio eletrônico. Para ter acesso basta acessar o sítio http://bdtd2.ibict.br/ 